\title{
Correction to: Race
}

\author{
Iris D. Ruiz and Raúl Sánchez
}

Correction to:

Chapter 1 in: I.D. Ruiz, R. Sánchez (eds.), Decolonizing Rbetoric and Composition Studies, DOI 10.1057/978-1-137-52724-0_1

This book was inadvertently published with the following errors in Chap 1 : Page 3: "to" has been missed from "do not seem matter" Page 11: Linda Brodkey has been wrongly cited.

The updated online version for this chapter can be found under https://doi.org/10.1057/978-1-137-52724-0_1

I. D. Ruiz $(\bowtie)$

University of California - Merced, Merced, California, USA

R. Sánchez

University of Florida, Gainesville, Florida, USA

(C) The Author(s) 2019 